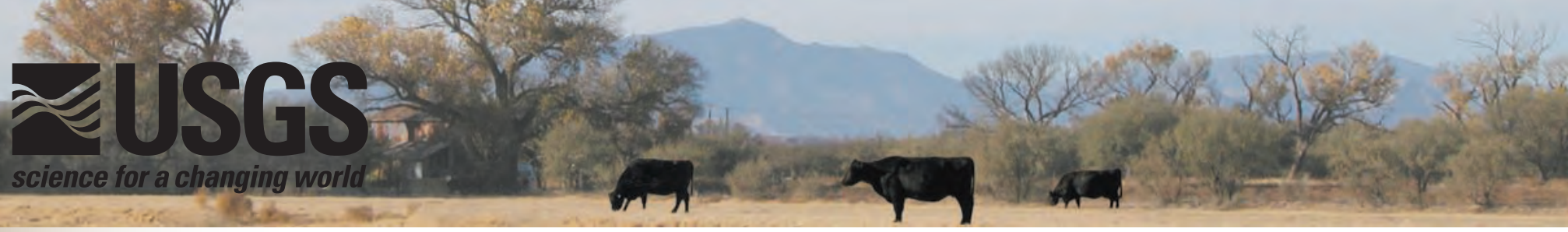

Prepared in cooperation with the

ARIZONA DEPARTMENT OF WATER RESOURCES

\title{
Hydrogeologic Investigation of the Middle San Pedro Watershed, Southeastern Arizona: A Project of the Rural Watershed Initiative
}

The middle San Pedro watershed is a northwest-southeast trending basin in Cochise and Pima Counties in southeastern Arizona (fig. 1). The watershed includes parts of two groundwater basins designated by the Arizona Department of Water Resources: the southern part of the Lower San Pedro Basin and the northern part of the Upper San Pedro Basin. Benson is the largest city in the watershed and had a population of about 4,900 in 2005 . The population of the watershed has grown moderately by a factor of about 1.5 during the past 20 years (Arizona Department of Water Resources, 2005; U.S. Census Bureau, 2006), but it is expected to rapidly increase during the next 20 years as residential developments are constructed for retirement communities or for satellite communities of nearby Tucson, Arizona. If the approved and planned developments are constructed as scheduled, the population of Benson is expected to increase to more than 50,000 by 2025 ("Arizona Daily Star," 2005).

Ground water is the primary source of water and is essential to support a growing population, agriculture, industry, and the riparian habitat of the San Pedro River. The city of Benson, Cochise County, the public, and other interested parties are concerned about the future availability and sustainability of the water supply. Increased groundwater pumping could have several undesirable consequences, such as (1) loss of available ground-water storage, (2) increased cost of pumping, (3) need for deepening existing wells, (4) need for new wells, (5) decreased quality of

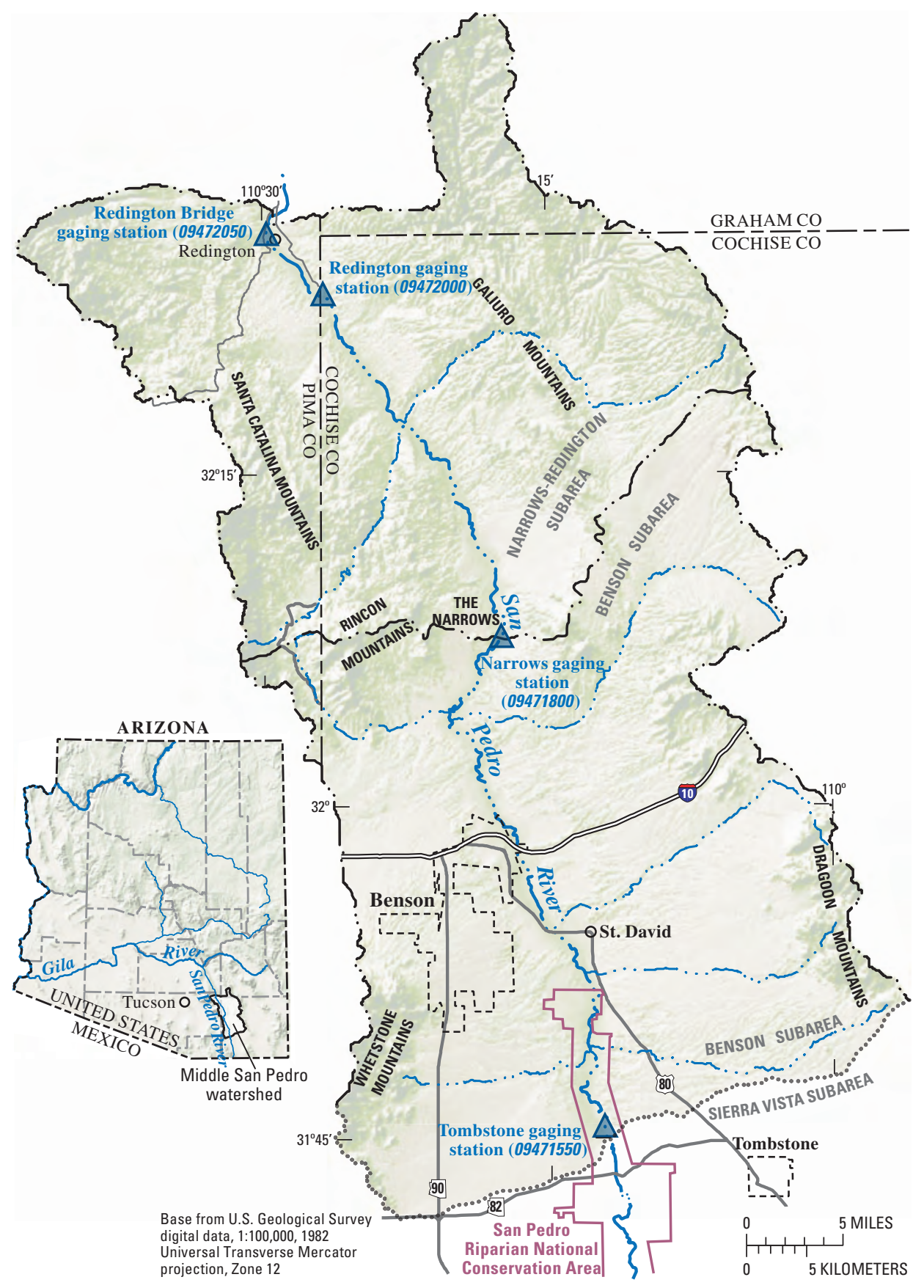

Figure 1. Location of middle San Pedro watershed, southeastern Arizona. 
drinking water, (6) land subsidence, and (7) damage to the riparian habitat of the San Pedro River. To be effective and acceptable to all interested parties, planning and management of the groundwater supply needs to be guided by an objective and comprehensive scientific understanding of the ground-water system.

In 2005, the U.S. Geological Survey (USGS) began an investigation of the hydrogeology of the middle San Pedro watershed in cooperation with the Arizona Department of Water Resources (ADWR). This project is part of the Rural Watershed Initiative (RWI), which is a program established by the State of Arizona and managed by the ADWR. Other RWI projects that started in 2005 include an investigation of several basins in Mohave County in northwestern Arizona and an investigation of the Willcox and Douglas Basins in southeastern Arizona. RWI projects that started in 1999 include studies of the Coconino Plateau in northern Arizona, the Mogollon Highlands in central Arizona, and the upper and middle Verde watersheds in central Arizona (Arizona Water Science Center, 2003).

The primary objective of this project is to improve the understanding of the hydrogeology of the middle San Pedro watershed. Specific objectives are to:

1. Assess the current state of knowledge of the ground-water system.

2. Describe and quantify the hydrogeologic framework.

3. Describe and quantify the groundwater flow system, including recharge, discharge, water in storage, and historical changes in the system.

4. Construct a predictive numerical model of the ground-water system that can be used to help guide decisions by planners and water managers about future development.

\section{Physical Setting and Surface Water}

The area of the middle San Pedro watershed is about $1,370 \mathrm{mi}^{2}$, the length is about $50 \mathrm{mi}$, and the average width is about $25 \mathrm{mi}$. Land-surface altitudes range from about 2,800 to $5,000 \mathrm{ft}$ for the alluvial valley and basin upland and from about 5,000 to 8,700 ft for

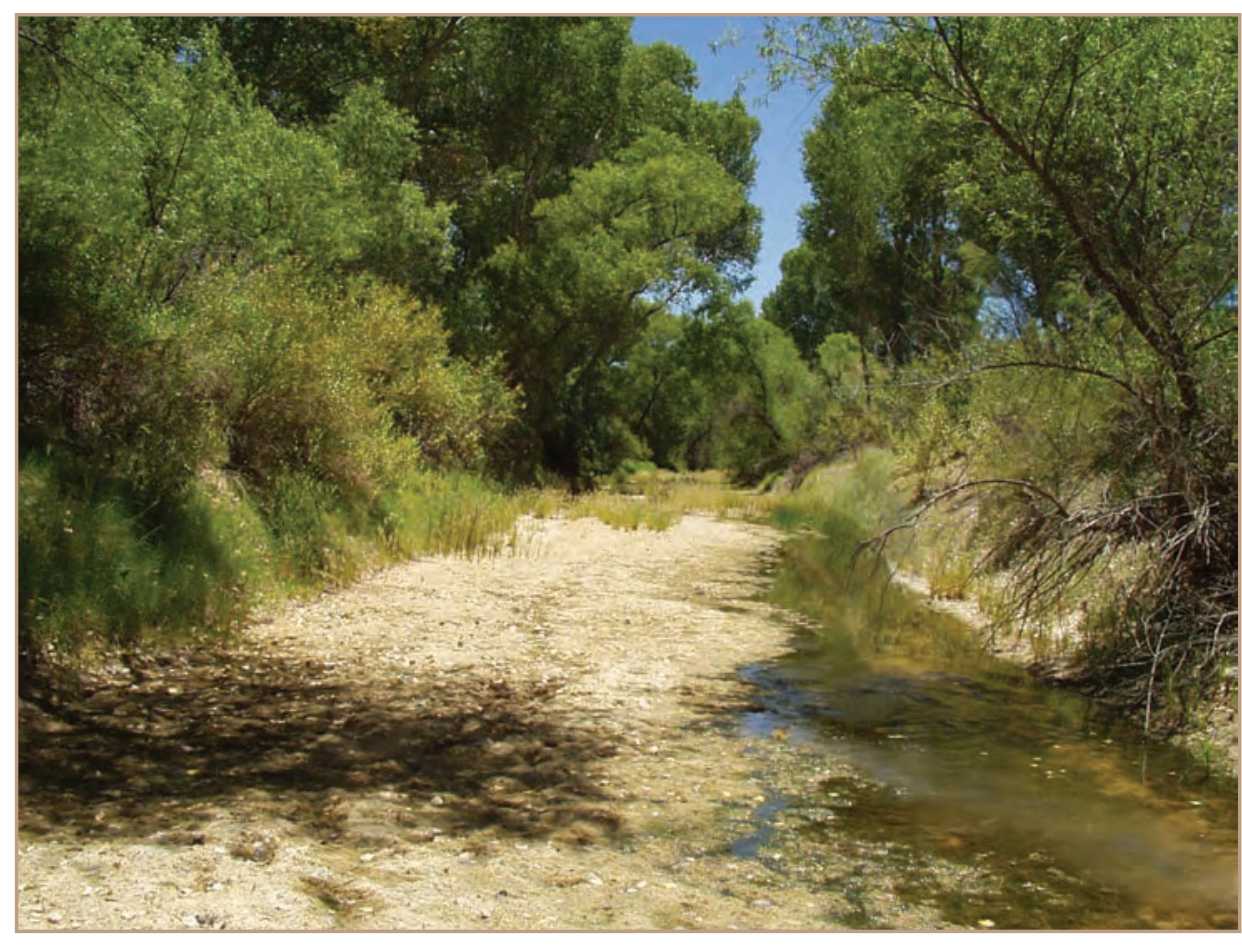

Figure 2. Riparian vegetation of the San Pedro River in the middle San Pedro watershed, southeastern Arizona.

the surrounding bedrock mountains. The middle watershed is divided into two subareas: (1) the Benson subarea is from the boundary with the Sierra Vista subarea on the south to the Narrows on the north, and (2) the Narrows-Redington subarea is from the Narrows to a streamflow-gaging station near Redington on the north (fig. 1). The Narrows is at a constriction in the basin where bedrock mountains extend into the watershed from the east and west.

The climate of the study area is arid to semiarid with hot summers and mild winters. Average annual precipitation ranges from about 11 to $16 \mathrm{in}$. in the alluvial valley and basin upland, and from about 16 to $25 \mathrm{in}$. in the mountains (Western Regional Climate Center, 2005; Spatial Climate Analysis Service, 2003). Vegetation is diverse; the riparian forest near the San Pedro River includes cottonwood, willow, salt cedar, and mesquite trees (fig. 2), the basin upland includes grasslands, desert scrub, and mesquite trees, and the mountains typically have oak woodlands in the lower altitudes and ponderosa pine in the highest altitudes (Kepner and Edmonds, 2002).

The San Pedro River drains the study area and flows from south to north from its origins in Mexico to the Gila River north of the study area. The river is mostly ephemeral in the study area with a few short reaches of perennial flow in areas where the ground-water table is near land surface or where ground water flows upward. Average annual streamflow for concurrent records (1970-85) at gaging stations in the study area was 43,000 acre-ft at Tombstone at the southern boundary and 37,000 acre-ft at Redington near the northern boundary. Annual streamflow near Redington decreased by about 70 percent from the mid-1940s (about 35,000 acre-ft) to the late 1990s (about 10,000 acre-ft; fig. 3). Possible causes of this decreasing trend in flow are decreases in precipitation, changes in upland land-cover and riparian vegetation, and increases in ground-water pumping (Thomas and Pool, in press).

\section{Hydrogeologic Framework}

The hydrogeologic framework of a ground-water system describes the boundaries and internal properties of the aquifers and confining beds in the system. An aquifer is geologic material that can transmit usable quantities of water to wells. The geologic material of aquifers typically is coarse-grained sediments that have larger pore spaces between the solid particles and higher permeability than fine-grained sediments. Most usable water in storage in a ground-water system comes from the aquifers. Confining beds 


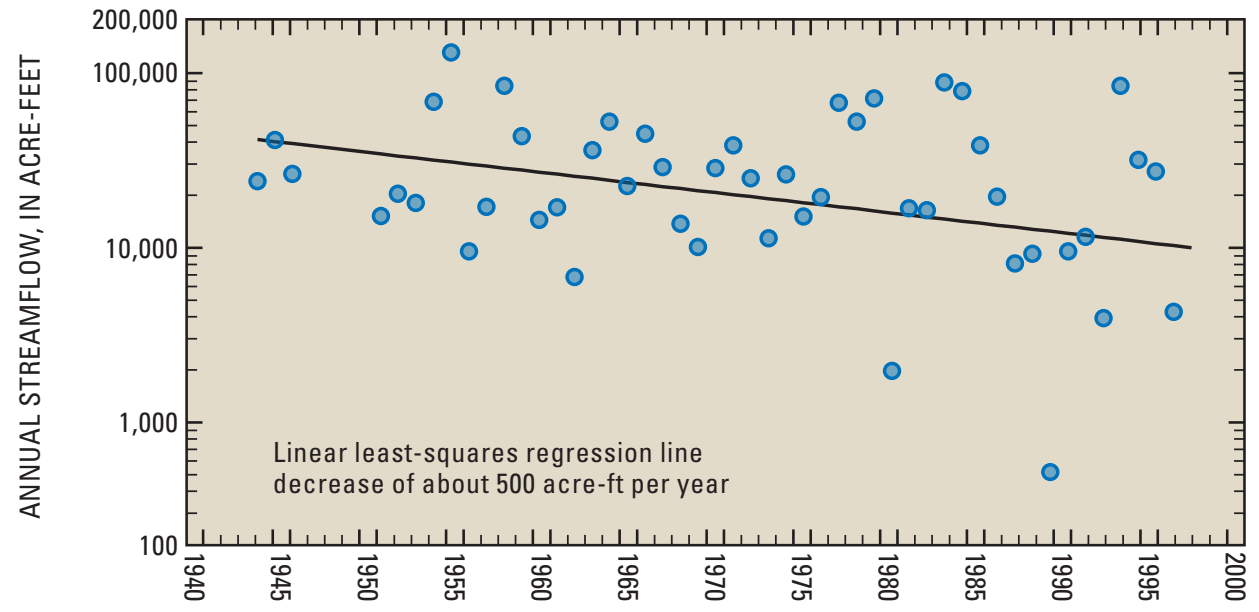

Figure 3. Annual streamflow of San Pedro River near Redington, Arizona (09472000), 1944-97.

typically are fine-grained sediments that restrict the vertical movement of water either into or out of adjacent aquifers. Confining beds strongly influence the movement of ground water and the effects of ground-water pumping (Heath, 1989).

Ground water in the middle San Pedro watershed occurs primarily in the basin fill, which is unconsolidated deposits of clay, silt, sand, and gravel. The lateral boundaries of the basin fill are the bedrock mountains bordering the east and west sides of the watershed, and the lower boundary is the underlying bedrock (fig. 4). Bedrock is mostly composed of granite, sandstone, and limestone. The aquifers in the ground-water system are mostly composed of sands and gravels, and the confining beds are composed of clays and silts.

The hydrogeologic framework is moderately well defined in the Benson subarea and poorly defined in the Narrows-Redington subarea (Arizona Department of Water Resources, 1994; Arizona Department of Water Resources, 2005). In the Benson subarea, there is a regional aquifer in the basin fill and a small local aquifer in the alluvial material of the flood plain of the San Pedro River. The regional basin-fill aquifer is mostly unconfined on the margins of the watershed and mostly confined (artesian) in the center of the watershed. The thickness of the basin fill varies widely by location and ranges from about $150 \mathrm{ft}$ to more than 2,000 ft (Arizona Department of Water Resources, 2005). The flood-plain aquifer generally is less than $50 \mathrm{ft}$ thick and ranges in width from tens of feet to almost 2 miles. The
St. David Formation is an important feature of the ground-water system in the Benson subarea. It consists of as much as $900 \mathrm{ft}$ of clays, silts, and some freshwater limestone. The formation contains clay layers that are as much as $300 \mathrm{ft}$ thick near the center of the Benson subarea. These clay layers act as a confining bed that restricts vertical movement of ground water and creates confined or artesian conditions in the underlying aquifer (Goode and Maddock, 2000). Other small and localized confining beds are scattered throughout the system, and they influence ground-water movement in the local areas.

The ground-water system in the Narrows-Redington subarea is similar to the system in the Benson subarea. Both have a regional aquifer in the basin fill and a local aquifer in the flood-plain alluvium. Two principal differences between the subareas are (1) the Narrows-Redington basin-fill aquifer

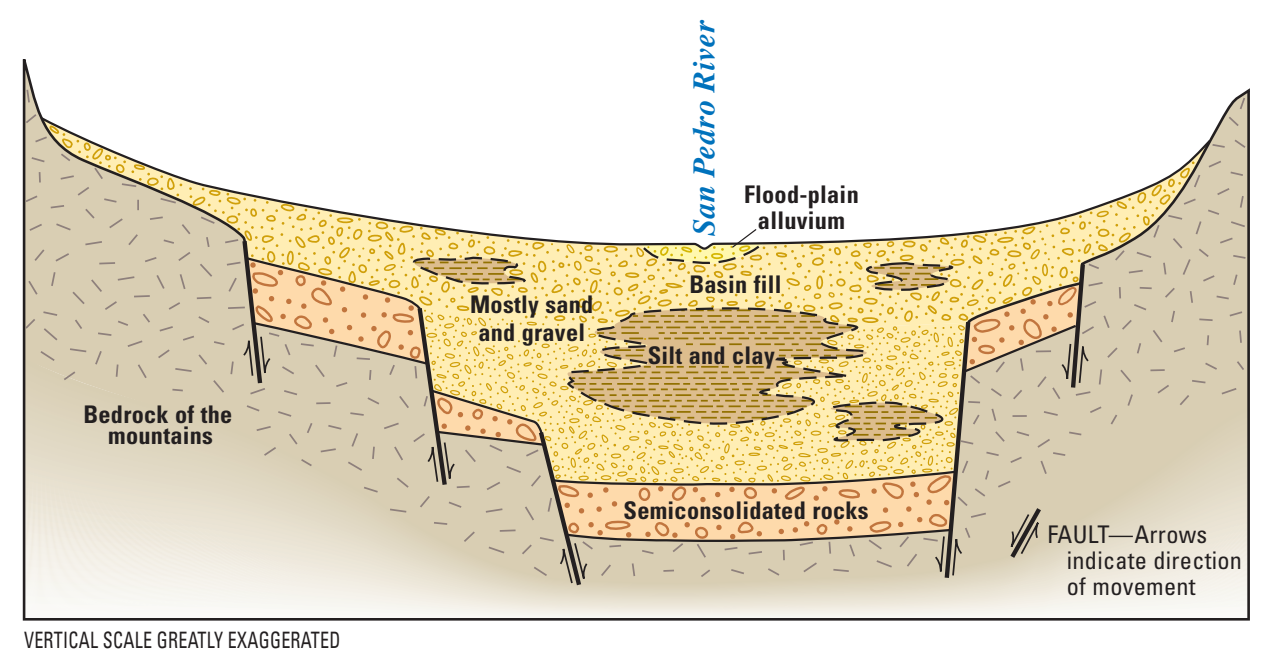

VERTICAL SCALE GREATLY EXAGGERATED

Figure 4. Generalized geologic section of the middle San Pedro watershed, southeastern Arizona. is smaller than the Benson basin-fill aquifer - it is narrower and thinner (likely less than 1,000 ft thick)—and (2) the principal confining bed (Quiburis Formation) in the Narrows-Redington basin fill is likely thinner and less effective in restricting vertical groundwater movement than the St. David Formation in the Benson basin fill (Lombard, 2004). The flood-plain aquifer in the Narrows-Redington subarea likely has a similar thickness as the flood-plain aquifer in the Benson subarea (less than $50 \mathrm{ft}$ ), but it is not as wide.

\section{Ground-Water Flow System}

Ground water in the basin fill generally flows from the mountains on the eastern and western sides of the study area to the San Pedro River flood plain and from south to north following the gradient of the river. Most recharge is from infiltration of rainfall and runoff in and near the mountains. Most discharge is from evaporation from the shallow water table in the San Pedro River flood plain and transpiration by riparian vegetation in the flood plain. Total recharge is estimated to be about 18,000 acre-ft/ yr in the Benson subarea (Arizona Department of Water Resources, 2005) and 11,000 acre-ft/yr in the Narrows-Redington subarea (Arizona Department of Water Resources, 1994). Ground-water pumpage in 2002 was about 9,000 acre-ft/yr in the Benson subarea and 9,000 acre-ft/yr in the Narrows-Redington subarea (Arizona Department of Water Resources, 1994 and 2005). Thus, in 2002, pumpage was about 50 percent of recharge in the Benson subarea and 80 percent of recharge in 
the Narrows-Redington subarea. This percentage is smaller than that for many other ground-water basins in southeastern Arizona (Arizona Department of Water Resources, 1994), but pumpage will increase substantially as residential developments are constructed and municipal and domestic demands increase.

\section{Ground-Water Quality}

The quality of ground water in the middle San Pedro watershed is generally suitable for domestic, municipal, agricultural, industrial, and stock uses. In the Benson subarea, the total dissolved solids (TDS) concentration typically is between about 200 and $400 \mathrm{mg} / \mathrm{L}$ (Arizona Department of Water Resources, 2005). Of 15 water samples collected during 1996-97 in the Benson subarea, 2 samples exceeded the U.S. Environmental Protection Agency (USEPA) Secondary Maximum Contaminant Level (SMCL) of $500 \mathrm{mg} / \mathrm{L}$ (Coes and others, 1999). SMCLs are aesthetic based and are not enforceable. High concentrations of TDS can corrode some materials and can impart an unpleasant taste to drinking water (U.S. Environmental Protection Agency, 2005). There is about a $9-\mathrm{mi}^{2}$ area of contaminated shallow ground water about 2.5 mi southwest of St. David. Operations at Apache Nitrogen Products (formerly known as Apache Powder Company) resulted in high concentrations of nitrate and perchlorate in ground water. The site has been designated as a USEPA Superfund site, and extensive remediation activities are currently being used to control and clean up the contamination (Arizona Department of Environmental Quality, 2006). The TDS concentrations in the Narrows-Redington subarea (about 200 to $600 \mathrm{mg} / \mathrm{L}$ ) generally are higher than those in the Benson subarea. Of 21 water samples collected during 2000 in the Narrows-Redington subarea, 5 samples exceeded the USEPA SMCL of $500 \mathrm{mg} / \mathrm{L}$ (Towne, 2005).

\section{Planned Approach of Investigation}

The investigation will consist of (1) an evaluation of existing data and information, (2) data collection and monitoring, (3) analysis and interpretation of the existing and new data, and (4) production of a Web site and reports describing the results of the study. Several complementary methods will be employed to achieve the study objectives. Existing data and information will be compiled and analyzed to enhance the knowledge of the ground-water system and to identify data gaps where the project should focus parts of the investigation. The hydrogeologic framework will be defined using geophysical methods, existing geologic information, and information from existing wells, such as lithologic logs, borehole geophysical logs, and ground-water levels.

Characteristics of the ground-water flow system, including recharge, discharge, storage, flow directions, and changes over time, will be defined using existing information and new data collected during the study. Such new data will include measurements and descriptions of the characteristics of soils, upland and riparian vegetation, agricultural crops, spring flows, and ground-water chemistry; and measurements of changes over time in precipitation, ground-water levels, ground-water storage, groundwater pumpage, and streamflow of the San Pedro River and its tributaries. A predictive numerical model of the ground-water system will be constructed by using results of the study. The model will be capable of estimating changes to the ground-water system caused by increased pumpage or changes in recharge or discharge. A long-term hydrogeologic monitoring network will be established to determine changes in ground-water levels and storage over time, and effects of ground-water pumpage.

\section{-Blakemore E. Thomas}

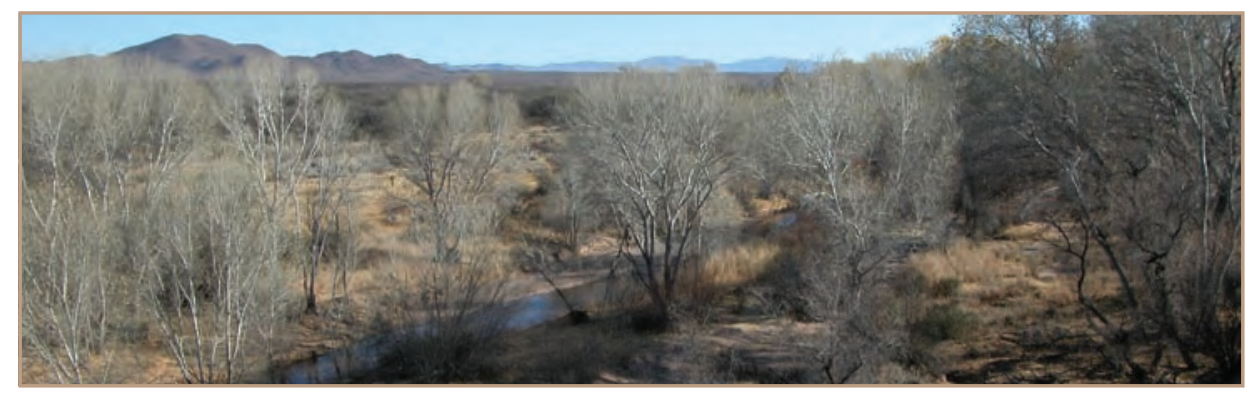

\section{References Cited}

Arizona Daily Star, 2005, Growth crawls toward Benson: Arizona Daily Star newspaper article on March 27, 2005, accessed July 25, 2005, at URL http://www.dailystar.com/

Arizona Department of Environmental Quality, 2006, accessed January 4, 2006, at URL http:// azdeq.gov/environ/waste/spr/download/state/ apache.pdf

Arizona Department of Water Resources, 1994, Arizona water resources assessment, volume II, hydrologic summary, August 1994: Arizona Department of Water Resources, 236 p.

Arizona Department of Water Resources, 2005, Groundwater resources of the Upper San Pedro Basin, Arizona, technical report to the Upper San Pedro Basin AMA review report: Arizona Department of Water Resources, 91 p.

Arizona Water Science Center, 2003, Arizona Rural Watershed Initiative, accessed January 5, 2006, at URL http://az.water.usgs.gov/rwi-ii/.

Coes, A.L., Gellenbeck, D.J., and Towne, D.C., 1999, Ground-water quality in the Sierra Vista subbasin, Arizona, 1996-97: U.S. Geological Survey Water-Resources Investigations Report 99-4056, 50 p.

Goode, T.C., and Maddock, Thomas III, 2000, Simulation of groundwater conditions in the Upper San Pedro Basin for the evaluation of alternative futures: University of Arizona, Tucson, Arizona, Department of Hydrology and Water Resources, HWR No. 00-030, 113 p.

Heath, R.C., 1989, Basic ground-water hydrology: U.S. Geological Survey Water-Supply Paper 2220, 84 p.

Kepner, W.G., and Edmonds, C.M., 2002, Remote sensing and geographic information systems for decision analysis in resource administration: A case study of 25 years of landscape change in a southwestern watershed: U.S. Environmental Protection Agency report EPA/600/R-02/039, 23 p.

Lombard, J.P., 2004, Results of Benson Narrows investigation-Contract AZFO-031031: Study conducted for the Arizona Chapter of the Nature Conservancy: James P. Lombard, R.G., private consultant, Tucson, Arizona.

Spatial Climate Analysis Service, 2003, PRISM products: Corvallis, Oregon, Oregon State University, accessed June 30, 2003, at URL http://www.ocs.orst.edu/prism/.

Thomas, B.E., and Pool, D.R., in press, Trends in streamflow of the San Pedro River, southeastern Arizona, and regional trends in precipitation and streamflow in southeastern Arizona and southwestern New Mexico: U.S. Geological Survey Professional Paper 1712.

Towne, 2005, Ambient groundwater quality of the Lower San Pedro Basin: A 2000 baseline study: Arizona Department of Environmental Quality Open-File Report 2002-01, 39 p.

U.S. Census Bureau, 2006, Annual estimates of the population for incorporated places in Arizona: U.S. Census Bureau accessed January 6, 2006, at URL http://www.census.gov/prod/www/abs/ decennial/index.htm

U.S. Environmental Protection Agency, 2005, List of Drinking Water Contaminants and MCLs, accessed December 15, 2005, at URL http:// www.epa.gov/safewater/mcl.html

Western Regional Climate Center, 2005, Arizona Climate Summaries, accessed December 16 , 2005, at URL http://www.wrcc.dri.edu/summary/ climsmaz.html/

For further information, contact: Blakemore E. Thomas U.S. Geological Survey Arizona Water Science Center 520 North Park Avenue, Suite 221 Tucson, Arizona, 85719-5035 Email: bthomas@usgs.gov or visit home page at http://az.water.usgs.gov 